\title{
SINIF VE TÜRKÇE ÖĞRETMENİ ADAYLARININ YAZMA KAYGILARININ İNCELENMESI
}

\author{
INVESTIGATING THE WRITING ANXIETY OF PRIMARY EDUCATION AND \\ TURKISH LANGUAGE TEACHER CANDIDATES
}

\author{
Dilan KALAYCI ${ }^{1}$ - Tolga ERDOĞAN ${ }^{2}$
}

\section{$\ddot{O} \mathbf{z}$}

$\mathrm{Bu}$ araştırmanın amacı, sınıf ve Türkçe öğretmeni adaylarının yazma kaygılarını çeşitli değişkenler açısından incelemektir. Araştırma, 2016-2017 eğitim yılı güz döneminde Karadeniz Teknik Üniversitesi Sınıf ve Türkçe Öğretmenliği programında okumakta olan 521 öğretmen adayı ile gerçekleştirilmiştir. Verilerin toplanması, analizi ve yorumlanmasında karma yöntem kullanılmıştır. Araştırmanın nicel boyutunda, öğretmen adaylarının yazma kaygılarını belirlemek için 'Yazma Kaygısı Ölçeği' kullanılmıştır. Nitel boyutunda ise adaylarla yarı yapılandırılmış görüşmeler yapılmıştır. Nicel bulgular uygun istatistiksel tekniklerle analiz edilirken nitel bulguların analizinde betimsel analizden yararlanılmıştır. Araştırma sonucunda, öğretmen adaylarının yazma kaygılarının düşük düzeyde olduğu, yazma kaygılarında cinsiyet, program, akademik ortalama değişkenlerinin etkili olmadığı, sınıf seviyesi değişkeninin ise etkili olduğu görülmüştür. Ayrıca öğretmen adaylarıyla yapılan görüşmelerde genel olarak yazmayı sevmedikleri ve yazmayla ilgili kaygı yaşadıkları sonucuna ulaşılmıştır.

Anahtar Kelimeler: Yazma, yazma kaygısı, öğretmen adayı.

\begin{abstract}
The aim of this research is to examine the writing anxiety of primary education and Turkish language teacher candidates in terms of various variables. The research was conducted with 521 teacher candidates who are studying in Karadeniz Technical University Class and Turkish Language Teaching Program during the fall semester of 2016-2017 education year. The mixed method was used in the collection, analysis and interpretation of the data. In the quantitative dimension of the research, 'Writing Anxiety Scale' was used to determine the writing anxiety of the teacher candidates. In the qualitative dimension, semi-structured interviews were held with the candidates. While quantitative findings were analyzed with appropriate statistical techniques, descriptive analysis was used in the analysis of qualitative findings. As a result of the research, it is found that the teacher candidates' writing anxiety were low and gender, program, academic success average variables were not effective in writing anxiety, and grade level variable was effective. In addition, interviews with teacher candidates have generally reached the conclusion that they do not like to write and have anxieties about writing.
\end{abstract}

Keywords: Writing, writing anxiety, teacher candidate.

\footnotetext{
${ }^{1}$ Karadeniz Teknik Üniversitesi, Türkçe Eğitimi Bölümü, dilankalaycii@gmail.com

2 Doç.Dr., Karadeniz Teknik Üniversitesi, Temel Eğitim Bölümü, tolgaerdogan.edu@gmail.com
} 


\section{GíRiş}

Öğrencinin duygu ve düşüncelerini aktarması, iletişim kurması ve kendini ifade etmesinde dört temel dil becerisi içerisinde yer alan yazma becerisi önemli rol oynar. Aynı zamanda akademik başarı için gerekli olan (Dedeyn, 2011) yazma becerisi; dinleme, konuşma ve okuma gibi diğer temel dil becerilerinin kazanılmasından sonra kazanılabilecek bir beceri alanıdır (Karakaya ve Ülper, 2011). Yazma, kendimizi ifade etmekten bilgi aktarımına kadar çeşitli amaçlarla kullandığımız süreç odaklı bir beceridir. Herhangi bir konuda duygu, hayal ya da özgün fikirleri belli bir düzen ve bütünlük içinde yazıya geçirme işine yazma denir. (Göçer, 2010). Beynin hem sağ hem de sol yarım küresini aktif hale getirerek mümkün olan en yüksek seviyede çalışmasını sağlayan (Emig, 1977;125) yazma, medeniyetlerin şekillenmesinde, kültür aktarımında ve fikirlerin etkili iletişiminde vazgeçilmeyen bir araçtır (Tok ve Potur, 2015).

Öğrencilerin en çok zorlandıkları üst düzey bir beceri olan yazmayı öğrenmek zaman alır. Yazmayı öğrenmek; motivasyonu ve beceriyi geliştirmeye yönelik dikkat gerektiren sıradış1, karmaşık dilsel ve bilişsel bir iştir (Bruning ve Horn, 2010). Eğitim sürecinin temel taş1 olma görevini üstlenen ve müfredat dâhilinde olan yazma (Calhoun ve Haley, 2003) süreklilik kazandığında gelişir. Yazma eyleminin doğasından kaynaklanan bazı zorluklar öğrencilerin yazmadan zevk almasını ve bunu yaşam boyu kullanılacak bir beceri haline getirmesini zorlaştırmaktadır (Yaman, 2010). Yazma becerisi; hedef dilin yazım kurallarına, noktalama işaretlerine ve zengin kelime dağarcığına hâkim olmak şartı ile tamamlandığı için, bu zorluklar öğrencilerde farklı duygu durumları açığa çıkarır ve bunlardan biri de kaygıdır. Kayg1; 'Tehlike hissedildiğinde güçsüzlüğe göre ortaya çıkan duygusal bir durumdur (Ellis 1994 'ten akt. Bayat 2014; 1134). Kayg1, doğal ve çevre kaynaklı olmak üzere iki şekilde açığa çıkar (Woodrow, 2011; 511).

Yazma sürecini aksatan, negatif, endişeli duygu durumu olarak da bilinen (McLeod, 1987) yazma kaygısı, yazmaya karşı gelişen bir tepkidir (Güneyli, 2016; 165). Yazma kaygısı hisseden öğrenciler yazmaktan çekinirler ve yazı yazmayı gerektiren ödevlerden uzak dururlar. Bu durum öğrencilerin akademik başarılarını düşürür. Böylece kendilerini endişeli ve kayg1lı hissederler (Daly ve Miller, 1975; Daly, 1978).

Birey kendini yazma becerisi yönünden zayıf ve yetersiz görüyorsa bu yetersizlik hissi yazma kaygısına sebep olabilmektedir (İşeri ve Ünal, 2012). Öğrenciler yazma kaygısı ile basit metinler oluşturmaktan karmaşık raporlar yazmaya kadar pek çok sorun yaşamaktadır (Schweiker-Marra ve Marra, 2010; 99). Kaliteli yazma hususunda yazma kaygısının pek çok değişkene dayandığı görülmektedir (Cheng, 2002; 648). Öğretim programında yazma sürecine yönelik yüksek beklentiler (Martinez, Kock ve Cass, 2011) ile yazıda hataların okurun gözü önünde olması yazma becerisini dilbilgisel açıdan zor bir beceri haline getirir (Öztürk, 2012) ve öğrenmek için ideal olan orta düzey kayg1 (Sevim ve Özdemir Erem, 2013) fazlalaştırılmış olur.

Son y1llarda yazmada motivasyonun rolüne olan ilginin de artması ile (Graham, Berninger, Fan, 2007) daha çok okul bağlamında sınırlandırılan yazma kaygısı (Kurt ve Atay, 2007), adını sık duyduğumuz bir kavram haline gelmiştir. Yazmada yaklaşımlar bilişsel sürece odaklanır (Petrosko, Kaiser ve Dietrich, 1984) ancak, ileri düzey bir metni yazmak için yalnızca dil sistemi değil (Kellogg, 2008), bireyin duygusal hazırbulunuşluğu da önemlidir. Yazmayı zor ve üstesinden gelinmesi güç olarak gören kişilerin yazmayla ilgili her durumdan kaçınması (Aytan ve Tunçel, 2015) etkili öğrenmeyi engeller. Kaygının performansta hem olumlu hem de olumsuz etkilerinin olduğu yaygın olarak bilinse de (Lehrer,Goldman ve

Strommen, 1990), eğitim-öğretim uygulamalarında, öğrencinin yazma eylemini gerçekleştirirken zamanının sınırlanması, yazmanın eylem sonunda puanlandırılacak olması 
ya da yazdığı metni sınıf ortamında paylaşacak olması başarıya ket vuran faktörlerdendir. $\mathrm{Bu}$ kaygı ile, yazmada yaşadığı sorunlara yardımcı olabilecek yöntemlerden dahi uzak duran birey (Güneyli, 2016) için ilk ve temel kaynak öğretmen olacaktır.

Öğretmenlik mesleğini yapacak olan bireylerin dört temel dil becerilerinin olabildiğince gelişmesi beklenmektedir (İşeri ve Ünal, 2012). Öğrencideki yazma becerisini geliştirmek ancak öğretmenin yazma becerisindeki bireysel donanımı ile mümkündür. Yüksek düzeyde kaygı ise bu gelişimi olumsuz olarak etkiler. Özellikle sınıf ve Türkçe öğretmenleri için nitelikli bir yazılı metin üretebilme becerisine sahip olmak her şeyden önce mesleki bir gerekliliktir (Karakaya ve Ülper, 2011). Bu beceri için de öğretmen adaylarının yazma konusunda yüksek düzeyde kaygı yaşamamaları gerekmektedir.

Sınıf ve Türkçe öğretmeni adaylarının yakın gelecekte yazma eğitimine ihtiyacı olan bir okulda bu eğitimden sorumlu bireyler olacakları (Street, 2003) düşünüldüğünde; yazma eğitiminde ilk adım olan sınıf öğretmeni ve sonrasında Türkçe öğretmen adaylarının, lisans düzeyinde kaygı düzeylerinden yola çıkılarak yetiştirilme süreci ve bu süreçte yazma becerisiyle ilgili durumları elde edilen nicel ve nitel veriler doğrultusunda, bu çalışmada ele alınmıştır.

Alan yazında; öğretmen adaylarının yazma, yazma kaygısı ve metin oluşturma süreciyle ilgili çalışmalar yer almaktadır (Teichman ve Poris, 1989; Göçer, 2010, Gallavan, Bowles, ve Young, 2012, İşeri ve Ünal, 2012, Bayat, 2014, Wynne, Guo ve Wang, 2014; Kardaş, 2015). İşeri ve Ünal (2012), Niğde Üniversitesi Türkçe Eğitimi Bölümü öğrencileriyle yaptıkları araştırmada, adayların kaygı düzeylerini düşük bulmuş ve yazma sıklığı arttıkça yazma kaygılarının düştügünü gözlemlemişlerdir. Kardaş (2015), iki dilli Türkçe öğretmeni adaylarının Türkçe yazılı anlatım becerisi ile Türkçe yazma kaygısını belirlemiş, adayların yazma kaygısını orta düzey bulmuş, ayrıca Türkçe yazılı anlatım becerisi düzeyleri ve yazma kaygısı durumlarının birbirine paralel olduğunu belirtmiştir. Teichman ve Poris (1989), bilgisayar ve el ile yazım arasındaki farkın yazma kaygısına etkisini araştırdıkları çalışmalarında, iki tip yazım şekli arasında çok büyük bir farkın olmadığını ortaya koymuşlardır. Gallavan, Bowles ve Young (2012), öğretmen adaylarının yazma becerilerine yönelik yaptıkları çalışmada, adayların yazmadan hoşlanmadıklarını fakat nasıl öğretileceği konusunda kendilerine güvendiklerini anket sonuçlarına göre tespit etmişlerdir.

$\mathrm{Bu}$ çalışmalar dikkate alındığında sınıf ve Türkçe öğretmeni adaylarının yazma kaygılarının karma araştırma yöntemiyle incelendiği bir çalışmaya rastlanmamıştır. Bu nedenle, öğretmen yetiştirme sürecinin de rol oynadığı, öğrenciye ilk olarak sınıf, daha sonra da Türkçe öğretmeni aracılığı ile kazandırılan 'yazma becerisinde kaygının' öğretmen adaylarındaki düzeyi hem nicel hem de nitel veriler doğrultusunda belirlenmiştir. Bu bağlamda araştırmanın amacı, sınıf ve Türkçe öğretmen adaylarının yazma kaygı düzeylerini çeşitli değişkenler açısından incelemektir. Bu amaca ulaşmak için aşağıdaki sorulara yanıt aranmıştır:

1. Sınıf ve Türkçe öğretmeni adaylarının yazma kaygıları ne düzeydedir?

2. Sınıf ve Türkçe öğretmeni adaylarının yazma kaygıları cinsiyet, program, sınıf seviyesi ve akademik ortalamaya göre anlamlı bir farklılık göstermekte midir?

3. Sınıf ve Türkçe öğretmeni adaylarının yazma kaygılarına ilişkin görüşleri nelerdir?

\section{YÖNTEM}

\section{Araştırma Modeli}

Sınıf ve Türkçe öğretmeni adaylarının yazma kaygı düzeylerini belirlemek amacıyla yapılan bu çalışma tarama modeli ile yürütülmüştür. 'Tarama modeli, geçmişte ya da halen 
var olan bir durumu varolduğu şekliyle betimlemeyi amaçlayan araştırma yaklaşımlarıdır' (Karasar, 2015; 77).

Araştırmada elde edilen verilerin toplanması, analizi ve yorumlanmasında ise "karma yöntemden" yararlanılmıştır. Karma yöntemin temel sayıltısı nicel ve nitel yöntemlerin birlikte kullanılarak araştırma problemi ve sorularının daha iyi anlaşılacağı ve inceleneceği üzerinedir (Cresswell, 2008; Fraenkel ve Wallen, 2006). Karma yöntem; "yakınsayan paralel karma yöntem", "açımlayıcı sıralı karma yöntem" ve "keşfedici sıralı karma yöntem” deseni olmak üzere üçe ayrılmaktadır. Bu araştırmada "yakınsayan paralel karma yöntem" deseni kullanılmıştır. Bu yaklaşımda, araştırmacı nitel ve nicel verileri birlikte toplar. Ancak verileri ayrı ayrı analiz eder ve bulguların birbirini doğrulayıp doğrulamadığını belirlemek için bulguları karşılaştııır. Bu yaklaşımdaki temel varsayım nitel ve nicel verilerin farklı türde bilgi sağlamasıdır (Creswell, 2014). Bu araştırmada da öğretmen adaylarının yazma kaygıları hem nicel hem de nitel verilerle belirlenmiş ve bu verilerin birbirini destekleyip desteklemediği ortaya konulmuştur. Araştırmanın nicel boyutunda öğretmen adaylarının yazma kaygıları Yazma Kaygısı Ölçeği ile belirlenmiştir. Nitel boyutunda ise öğretmen adaylarıyla yarı yapılandırılmış görüşmeler yapılmıştır.

\section{Çalışma Grubu}

Araştırma Karadeniz Teknik Üniversitesi Sınıf ve Türkçe Öğretmenliği Anabilim Dalında 1, 2, 3 ve 4. sınıfta okuyan toplam 810 (Sınıf Öğretmenliği Anabilim Dalı 530 ve Türkçe Öğretmenliği 280) öğretmen adayı arasından rastgele seçilen 521 öğretmen adayı ile yürütülmüştür. Araştırmaya katılan öğretmen adaylarına ilişkin bilgiler Tablo 1'de verilmiştir.

Tablo 1. Çalışma Grubuna İlişkin Bilgiler

\begin{tabular}{ccc}
\hline Program & $\begin{array}{c}\text { Sinıf } \\
\text { Öğretmenliği }\end{array}$ & $\begin{array}{c}\text { Türkçe } \\
\text { Öğretmenliği }\end{array}$ \\
\hline Cinsiyet & 255 & 124 \\
Kız & 87 & 55 \\
Erkek & & 51 \\
\hline Sınıf & 86 & 44 \\
1.sinıf & 98 & 42 \\
2. sinıf & 55 & 43 \\
3. sinıf & 104 & 6 \\
$4 . \sin 1 f$ & & 46 \\
\hline Akademik Ortalama & 23 & 56 \\
\hline $2.00-2.49$ & 130 & 13 \\
\hline $2.50-2.99$ & 96 & 179 \\
\hline $3.00-3.49$ & 8 & \\
\hline Toplam & 342 & \\
\hline
\end{tabular}

Tablo 1'deki bulgular incelendiğinde, çalışma grubundaki öğretmen adaylarının çoğunluğunun sınıf öğretmeni adayı olduğu görülmektedir. Bu durum, evrene ilişkin sınıf 
öğretmeni adayı sayısının fazla olmasından kaynaklanmaktadır. Ayrıca adayların çoğunluğunun kız olduğu, dört sınıf düzeyinde de birbirine yakın sayıda adayın olduğu ve adayların akademik ortalamalarının ise genel olarak 2.50-3.49 arasında olduğu görülmektedir.

Araştırmada yapılacak görüşmeler için sınıf ve Türkçe öğretmenliği programının her sınıf seviyesinden akademik başarıları 'düşük, orta ve yüksek' olan 3'er öğrenci seçilmiştir. Böylece Sınıf ve Türkçe öğretmenliği programlarından 12'şer öğretmen adayı ile görüşme yapılmıştır. Görüşme yapılan öğrencilerin yarısı kız, yarısı ise erkektir.

\section{Veri Toplama Araçları}

Araştırmada öğretmen adaylarının yazma kaygılarını belirlemek için Karakaya ve Ülper (2011) tarafindan geliştirilen "Yazma Kaygısı Ölçeği”" kullanılmıştır. Ölçek, tek boyuttan oluşmakta ve 35 maddeyi içermektedir. Ölçeğin uygulandığı bireylerden, kendilerine sunulan uyarıcılara yönelik tepkilerini "Her zaman", "Çoğu zaman", "Ara sıra", "Çok seyrek" ve "Hiçbir zaman" şeklinde düzenlenmiş sıklık bildiren tepki kategorileri doğrultusunda belirtmeleri istenmiş; ölçekte yer alan maddeler, "her zaman" kategorisinin işaretlenmesi durumunda "5", "hiçbir zaman" kategorisinin işaretlenmesi durumunda "1" puan ile puanlanmıştır. Ölçekten en fazla 175, en az 35 puan alınabilir. Yüksek puan kaygı düzeyinin yüksek, düşük puan ise düşük olduğunu göstermektedir. Ölçeğin Cronbach Alpha iç tutarlılık katsayısı kullanılarak hesaplanan güvenirlik katsayısının da 0.97 olduğu görülmüştür (Karakaya ve Ülper, 2011).

Araştırmada öğretmen adaylarının sürece ilişkin görüşlerini almak için onlarla yarı yapılandırılmış görüşmeler yapılmıştır. Yarı yapılandırılmış görüşmede, katılımcıya önceden belirlenmiş sorular sorulur. Bunun yanı sıra gerekli görülen yerlerde yeni sorular sorulabilir veya bazı soruların sorulmasından vazgeçilebilir (Karasar, 2015). Yapılan görüşmeler için görüşme soruları hazırlanmış ve bu sorular için üç alan uzmanının görüşleri alınmıştır. Uzman görüşlerine göre sorulara son şekli verilmiştir.

\section{Verilerin Toplanması ve Analizi}

Araştırmada öğretmen adaylarının yazma kaygıları, Yazma Kaygısı Ölçeği ile belirlenmiştir. Bunun için ölçek araştırmacılar tarafından adaylara uygulanmıştır. Daha sonra ölçekten elde edilen veriler bilgisayar ortamına aktarılmış ve bir paket programında analiz edilmiştir. Araştırmada ilk olarak öğretmen adaylarının yazma kaygılarına ilişkin aritmetik ortalama ve standart sapmalar belirlenmiştir. Öğretmen adaylarının yazma kaygılarının cinsiyete ve programa göre anlamlı bir fark gösterip göstermediği bağımsız gruplar için $t$ testiyle, akademik ortalama ve sınıf seviyelerine göre ise tek yönlü varyans analizi (ANOVA) ile analiz edilmiştir.

Araştırmada yapılan görüşmeler araştırmacılar tarafindan öğretmen adaylarıyla yüz yüze gerçekleştirilmiştir. Öğretmen adaylarına araştırma amacına uygun, uzman görüşü alınmış, yaş, cinsiyet ve sınıf değişkenlerini de içeren sorular yöneltilmiştir. Görüşme, her bir aday için ortalama 20-25 dakika sürmüştür. Araştırmada yapılan görüşmelerde elde edilen veriler ses kayıt cihazı ile kaydedilmiş ve daha sonra kayıt altına alınan veriler düz metin hâline getirilmiştir. Ayrıca araştırmada elde edilen bulgular, öğretmen ve öğretmen adaylarının sorulara ilişkin verdiği cevaplardan aynen alıntılar yapılarak desteklenmiştir. Görüşmelerde elde edilen verilerin analizinde "betimsel analiz" tekniği kullanılmıştır. Betimsel analizde, elde edilen veriler daha önceden belirlenen temalara göre özetlenir ve yorumlanır. Betimsel analizde, görüşülen ya da gözlenen bireylerin görüşlerini çarpıcı bir biçimde yansıtmak amacıyla doğrudan alıntılara sık sık yer verilir (Yıldırım ve Şimşek, 
2013). Görüşme yapılan öğretmen adaylarından sınıf öğretmeni adayları 'ÖS', Türkçe öğretmeni adayları 'ÖT' ş̧eklinde kodlanmıştır.

\section{BULGULAR}

\section{Öğretmen adaylarının yazma kaygı düzeyleri nedir?}

Araştırmada ilk olarak öğretmen adaylarının yazma kaygı düzeyleri incelenmiştir. Öğretmen adaylarının yazma kaygı düzeylerine ilişkin veriler Tablo 2'de verilmiştir.

Tablo 2. Öğretmen Adaylarının Yazma Kaygısı Ölçeğinden Aldıkları Puanların Aritmetik Ortalamaları

\begin{tabular}{cccc}
\hline Program & $\mathrm{n}$ & $\bar{x}$ & Ss \\
\hline Sinıf & 342 & 79.78 & 27.54 \\
Türkçe & 179 & 82.16 & 31.05 \\
Toplam & 521 & 80.60 & 28.79 \\
\hline
\end{tabular}

Tablo 2'deki bulgular incelendiğinde, öğretmen adaylarının yazma kaygısı ölçeğinden aldıkları puanların ortalamasının 80.60 olduğu görülmektedir. $\mathrm{Bu}$ bağlamda öğretmen adaylarının yazma kaygılarının "çok seyrek" yani düşük düzeyde olduğu söylenebilir. Bununla birlikte sınıf öğretmeni adaylarının yazma kaygısı ölçeğinden aldıkları puanların ortalamasının 79.78, Türkçe öğretmeni adaylarının ise 82. 16 olduğu görülmektedir. Türkçe öğretmeni adaylarının yazma kaygı düzeyleri sınıf öğretmeni adaylarına göre daha yüksektir.

\section{Öğretmen adaylarının yazma kaygısı çeşitli değişkenler açısından farklıık gösterir mi?}

Öğretmen adaylarının yazma kaygısı ölçeğinden aldıkları puanların cinsiyete göre anlamlı bir fark gösterip göstermediğine ilişkin sonuçlar Tablo 3'de verilmiştir.

Tablo 3. Öğretmen Adaylarının Yazma Kaygısı Ölçeğinden Aldıkları Puanların

\begin{tabular}{ccccc}
\multicolumn{5}{c}{ Cinsiyete Göre t-Testi Sonuçları } \\
\hline Cinsiyet & $\mathrm{n}$ & $\bar{x}$ & Ss & $\mathrm{t}$ \\
\hline $\mathrm{K} 1 \mathrm{z}$ & 379 & 80.82 & 28.80 & \\
Erkek & 142 & 80.02 & 28.85 & .282 \\
\hline $\mathrm{p}<.05$ & & &
\end{tabular}

Tablo 3'teki bulgular incelendiğinde k1z öğretmen adaylarının yazma kaygısı ölçeğinden aldıkları puanların ortalamasının 80.82, erkek adayların ise 80.02 olduğu görülmektedir. Bu sonuca göre öğrencilerin yazma kaygıları cinsiyete göre anlamlı bir fark göstermemektedir $\left(\mathrm{t}{ }_{(519)}=.282, \mathrm{p}>.05\right)$. 
Öğretmen adaylarının yazma kaygısı ölçeğinden aldıkları puanların okudukları programa göre anlamlı bir fark gösterip göstermediğine ilişkin sonuçlar Tablo 4'de verilmiştir.

Tablo 4. Öğretmen Adaylarının Yazma Kaygısı Ölçeğinden Aldıkları Puanların Okudukları Programa Göre t-Testi Sonuçları

\begin{tabular}{cllll}
\hline Program & $\mathrm{n}$ & $\bar{x}$ & Ss & $\mathrm{t}$ \\
\hline Türkçe & 179 & 82.16 & 31.05 & \\
Sinıf & 342 & 79.78 & 27.54 & .897 \\
\hline
\end{tabular}

Tablo 4'teki bulgular incelendiğinde, Türkçe öğretmenliği programındaki öğretmen adaylarının yazma kaygı ölçeğinden aldıkları puanların ortalamasının 82.16, sınıf öğretmenliği programındaki adayların ise 79.78 'dir. Buna göre öğretmen adaylarının yazma kaygıları okudukları programa göre anlamlı bir farklılık göstermemektedir $\left(\mathrm{t}{ }_{(519)}=.897\right.$, $\mathrm{p}>.05)$.

Sınıf ve Türkçe öğretmeni adaylarının yazma kaygısı ölçeğinden aldıkları puanların sınıf seviyesine göre anlamlı bir fark gösterip göstermediğine ilişkin sonuçlar Tablo 5 ve 6'da verilmiştir.

Tablo 5. Sınıf Öğretmeni Adaylarının Yazma Kaygısı Ölçeğinden Aldıkları Puanların Sınıf Seviyesine Göre ANOVA Sonuçları

\begin{tabular}{ccccc}
\hline $\begin{array}{c}\text { Varyansın } \\
\text { kaynağ } 1\end{array}$ & Kareler toplamı & sd & Kareler ortalaması & $\mathrm{F}$ \\
\hline Gruplararası & 14798.155 & 3 & 4932.718 & \\
Gruplariçi & 243947.833 & 338 & 721.739 & 6.834 \\
Toplam & 258745.988 & 341 & & \\
\hline
\end{tabular}

Tablo 5'deki bulgular incelendiğinde sınıf öğretmeni adaylarının yazma kaygıları sınıf seviyesine göre anlamlı bir fark göstermektedir $\left(\mathrm{F}_{(3,385)}=6.834, \mathrm{p}<.05\right)$. Farkın hangi sınıflar arasında olduğunu belirlemek için yapılan Tukey Testi sonuçlarına göre 4. Sınıftaki öğretmen adaylarının yazma kaygıları 1,2 ve 3. sınıftaki öğretmen adaylarının yazma kaygılarından anlamlı derecede düşüktür.

Tablo 6. Türkçe Öğretmeni Adaylarının Yazma Kaygısı Ölçeğinden Aldıkları Puanların Sınıf Seviyesine Göre ANOVA Sonuçları

\begin{tabular}{ccccc}
\hline Varyansın kaynağı & Kareler toplamı & sd & Kareler ortalaması & F \\
\hline Gruplararası & 18106,963 & 3 & 6035.654 & \\
Gruplariçi & 153508,009 & 175 & 877.189 & 6.881 \\
Toplam & 171614,972 & 178 & & \\
\hline
\end{tabular}


Tablo 6'daki verilere göre, Türkçe öğretmeni adaylarının yazma kaygısı ölçeğinden aldıkları puanlar sınıf seviyelerine göre anlamlı bir farklılık göstermektedir $\left(\mathrm{F}_{(3,175)}=6.881\right.$, $\mathrm{p}<.05)$. Farkın hangi sınıflar arasında olduğunu belirlemek için yapılan Tukey Testi sonuçlarına göre 2, 3 ve 4 . sınıftaki öğretmen adaylarının yazma kaygıları 1. sınıftaki öğretmen adaylarının yazma kaygılarından anlamlı derecede düşüktür.

Sınıf ve Türkçe öğretmeni adaylarının yazma kaygılarının akademik ortalamalarına göre anlamlı bir farklılık gösterip göstermediğine ilişkin sonuçlar Tablo 7 ve 8'de verilmiştir.

Tablo 7. Sınıf Öğretmeni Adaylarının Yazma Kaygısı Ölçeğinden Aldıkları Puanların Akademik Ortalamalarına Göre ANOVA Sonuçları

\begin{tabular}{ccccc}
\hline $\begin{array}{c}\text { Varyansın } \\
\text { kaynağı }\end{array}$ & Kareler toplamı & sd & Kareler ortalaması & F \\
\hline Gruplararası & 3679.303 & 3 & 1226.434 & \\
Gruplariçi & 193020.728 & 253 & 762.928 & 1.608 \\
Toplam & 196700.031 & 256 & & \\
\hline
\end{tabular}

Tablo 7'deki veriler incelendiğinde sınıf öğretmeni adaylarının yazma kaygıları akademik ortalamalarına göre anlamlı bir farklılık göstermemektedir $\left(\mathrm{F}_{(3,385)}=1.608, \mathrm{p}>.05\right)$.

Tablo 8. Türkçe Öğretmeni Adaylarının yazma kaygısı ölçeğinden aldıkları puanların akademik ortalamalarına göre ANOVA sonuçları

\begin{tabular}{ccccc}
\hline Varyansın kaynağı & Kareler toplamı & sd & Kareler ortalaması & F \\
\hline Gruplararası & 7606.880 & 3 & 2535.627 & 3.131 \\
Gruplariçi & 93956.045 & 116 & 809.966 & \\
Toplam & 101562.925 & 119 & & \\
\hline
\end{tabular}

Tablo 8'deki veriler incelendiğinde Türkçe öğretmen adaylarının yazma kaygıları akademik ortalamalarına göre anlamlı bir farklılık göstermemektedir $\left(F_{(3,175)}=3.131, p>.05\right)$.

\section{Öğretmen adaylarının yazma becerisi ve yazma kaygısına yönelik görüşleri nelerdir?}

Öğretmen adaylarıyla yapılan görüşmelerde elde edilen bulgular aşağıda sunulmuştur.

\section{Dört Temel Dil Becerisi Arasında Yazma}

Yapılan görüşmelerde öğretmen adaylarına kendilerini dört temel dil becerisi içerisinde en çok hangisinde başarılı hissettikleri sorulmuştur. Bu soruya ilişkin öğretmen adaylarının cevapları Tablo 9'da verilmiştir. 
Tablo 9. Öğretmen Adaylarının En başarılı Oldukları Dil Becerileri

\begin{tabular}{cc}
\hline Beceriler & $\mathbf{f}$ \\
\hline Konuşma & 7 \\
Okuma & 6 \\
Yazma & 6 \\
Dinleme & 5 \\
\hline
\end{tabular}

Tablo 9'daki verilere göre, öğretmen adayları en çok konuşma becerisinde kendilerini başarılı hissettiklerini ifade etmişlerdir. Yazma becerisini ifade edenlerin sayısı da konuşma becerisine yakındır. Konuşma becerisini seçen katılımcılar, yazma becerisi ile kıyaslandığında, konuşmada kendilerini daha rahat ifade ettiklerini belirtmişlerdir. Konuyla ilgili öğretmen adaylarının görüşleri şu şekildedir: ÖS9: '....kendimi daha iyi ifade edebildiğim için konuşmada daha iyi olduğumu düşünüyorum', ÖT20: '....konuşmayı seviyorum çünkü bir topluma hitap etmek hoşuma gidiyor', ÖS3: '...hepsinde başarllyyım ama herhalde en çok konuşmada başarılıyım diyebilirim, kendimi daha iyi ifade ediyorum'

\section{Yazma Sevgisi}

Öğretmen adaylarının yazmayı sevme durumlarına ilişkin bulgular Tablo 10'da verilmiştir.

Tablo 10. Öğretmen Adaylarının Yazmayı Sevme Durumları

\begin{tabular}{llll}
\hline Durum & f & İfadeler & f \\
\hline \multirow{2}{*}{ Yazmayı seviyorum. } & & Beni rahatlatıyor. & 3 \\
& 5 & Düşünmemi sağliyor. & 2 \\
& Beni geliştiriyor. & 2 \\
& Kendimi rahat ifade ediyorum & 1 \\
\hline \multirow{2}{*}{ Yazmayı sevmiyorum. } & Aldı̆̆ım dersler yetersiz & 11 \\
& 19 & Kendimi ifade edemiyorum. & 4 \\
& & Yazma zaman kaybıdır. & 3 \\
& & Altyapım yetersiz. & 2 \\
\hline
\end{tabular}

Tablo 10'daki bulgulara göre, öğretmen adaylarının çoğunluğu yazmayı sevmediklerini ifade etmişlerdir. Yazmayı sevmediğini ifade eden öğretmen adaylarının büyük bir kısmı yazma becerisine yönelik alınan derslerin çok yetersiz olması, kendilerini ifade edememeleri ve buna zaman ayırmak istememeleri nedeniyle yazmayı sevmediklerini belirtmişlerdir. Konuyla ilgili adayların görüşleri șu şekildedir: ÖS16: '...bu beceriye dair aldı̆̆ım dersler beni kesinlikle tatmin etmedi', ÖT5: '...bu becerinin üstüne pek düşülmedi dersler sadece şekilsel olarak kaldı', ÖT21: '...Birinci sınıfta makale/deneme gibi örnekler yazdırıldı ama sadece dilbilgisi kurallarına bakıldı', ÖS18: '...bu beceriye yönelik aldiğım dersler şimdiye kadar beni tatmin etmedi, yazılı anlatım dersi almıştık işlenişi güzeldi ama konuşma daha ağırlıktaydı'. 
Öğretmen adaylarının bir kısmı yapılan görüşmelerde yazmayı sevdiklerini ifade etmişlerdir. Yazmayı seven 5 katılımcıdan 3'ü kendilerini rahatlattı̆̆ı, 2'si düşünmelerine yardımcı olduğu, 2'si kendilerini geliştirdiği ve 1'i de kendisini yazarak daha rahat ifade ettiği için yazmayı sevdiklerini belirtmişlerdir. Konuyla ilgili adaylar görüşlerini şu şekilde ifade etmişlerdir: ÖT10: '....Yazmayı seviyorum çünkü karşındaki muhatabı görmüyorsun, isteyen okur istemeyen okumaz yazdıklarını' , ÖS7: '... yazmayı seviyorum çünkü düşünmemi sağllyor mesela bu yüzden günlük tutarım'. ÖT11: '... kendimi geliştirmemi sağllyor, kendini dışa vurabilme imkanı veriyor'

\section{Yazma Kaygisı}

Öğretmen adaylarına yazma konusunda kaygılı olup olmadıkları sorulmuştur.

Tablo 11. Öğretmen Adaylarının Yazma Kaygısı Yaşama Durumları

\begin{tabular}{lclc}
\hline Yazma Kaygısı & $\mathbf{f}$ & İfadeler & f \\
\hline Kaygı & 9 & Kaygım yok. & 9 \\
yaşamıyorum. & & \\
\hline Kaygı yaşıyorum. & 13 & Yazının ölçme ve değerlendirmeye alınması & 5 \\
& Yazıda zaman sınırlaması & 4 \\
& Yazının paylaşılması & 4 \\
& Yazma becerisinde yetersizlik duygusu & 3 \\
& Öğretmen olma sorumluluğu & 3 \\
& Yazmayı sevmeme & 1 \\
\hline
\end{tabular}

Tablo 11'de görüldüğü üzere 24 katılımcının sadece 9'u yazmada kayg1 yaşamadıklarını belirtmişlerdir. Öğretmen adayları, yazılan yazıların ölçme ve değerlendirmeye alınması, yazıda zaman sınırlaması, yazının paylaşılması, yazma becerisinde yetersizlik duygusu ve ögretmen olma sorumluluğu gibi nedenlerle yazma kaygısı yaşadıklarını ifade etmişlerdir. Konuyla ilgili ö ğretmen adaylarının görüşleri şu şekildedir: ÖT15: '...yazdıklarımı pek paylaşmak istemem', ÖT12: '...başkalarının yazdı̆̆ım şeyleri okumast beni tedirgin eder. Buna not verilmesi de kaygllandırtyor', ÖS23: '...süre verdiklerinde panik oluyoruz ben yazmak istediklerimi o süre içinde kağıda dökemiyorum ki', ÖS24: '...hem belli bir zaman içinde hem de ölçülecek olması beni gerer, genelde bu kısıtlamalarla yazamam zaten. ÖT21: '...yazmayı sevmediğimden kaygım var ve ayrıca öğretmen olacă̆ım için kendimi sorumlu hissediyorum', ÖT6: '...öğretmen olacağımı bildiğim için bu biraz baskı oluşturuyor'.ÖT12: '... ögrretmen olacağım için bunu geliştirmem gerektiğini biliyorum ama olumsuz etkiliyor bu beni bence, yani zorunluluk duygusu engelliyor'

\section{TARTIŞMA, SONUÇ ve ÖNERİLER}

$\mathrm{Bu}$ araştırmada sınıf ve Türkçe öğretmeni adaylarının yazma kaygı düzeylerinin çeşitli değişkenler açısından incelenmesi amaçlanmıştır. Araştırmada elde edilen sonuçlar sınıf ve Türkçe öğretmeni adaylarının yazma kaygılarının düşük düzeyde olduğunu göstermektedir. Araştırmada elde edilen bu sonuç İşeri ve Ünal (2012) tarafindan yapılan 
araştırma sonuçlarını desteklemektedir. İlgili araştırmada da öğretmen adaylarının kaygı düzeyleri düşük çıkmıştır. Bu durum, öğretmen yetiştirme süreci açısından olumlu bir durum olarak değerlendirilebilir. Ayrıca araştırmada öğretmen adaylarının yazma kaygılarıyla ilgili nicel bulgular nitel bulgularla tutarlılık göstermemektedir. Öğretmen adaylarıyla yapılan görüşmelere ilişkin veriler incelendiğinde öğretmen adaylarının yarısından fazlasının yazmayla ilgili kaygı yaşadıkları görülmektedir. Öğretmen adayları derinlemesine yapılan görüşmelerde yazma kaygısı yaşadıklarını işaret eden ifadeler kullanmışlardır.

Araştırmada sınıf ve Türkçe öğretmeni adaylarının yazma kaygılarının cinsiyete göre anlamlı bir farklılık göstermediği görülmüştür. Araştırmada elde edilen bu sonuç Karakaya ve Ülper (2011), İşeri ve Ünal (2012) ve Tiryaki (2012) tarafından yapılan çalışmaların sonuçlarıyla tutarlılık göstermektedir. Bu çalışmalarda da öğretmen adaylarının ve üniversite öğrencilerinin yazma kaygılarının cinsiyet değişkeninden etkilenmediği sonucuna ulaşılmıştır. Bunun yanında ilköğretim öğrencileriyle yapılan bazı çalışmalarda ise yazma kaygısının cinsiyet değişkeninden etkilendiği ortaya konulmuştur (Uçgun, 2011; Zorbaz 2010). Bu durum, ilköğretim düzeyinde yazma kaygısını etkileyen cinsiyet değişkeninin üniversite düzeyinde etkili olmadığı şeklinde yorumlanabilir. Ayrıca bu durum öğretmen adaylarının yazma becerileri açısından olumlu görülmektedir (İşeri ve Ünal, 2012).

Araştırmada sınıf ve Türkçe öğretmeni adaylarının yazma kaygılarının okudukları programa göre bir farklılık göstermediği görülmüştür. Araştırmada elde edilen bu sonuç Tiryaki (2010) tarafından yapılan çalışmayla da tutarlılık göstermektedir. Tiryaki (2010) tarafından yapılan araştırmada alana (sözel, sayısal ve eşit ağırlık) göre üniversite öğrencilerinin yazma kaygılarında anlamlı bir fark bulmamıştır. Bununla birlikte araştırmada Türkçe öğretmeni adaylarının yazma kaygıları sınıf öğretmeni adaylarının yazma kaygılarından yüksek çıkmıştır. Bu durum, Türkçe öğretmeni adaylarının yazma becerisine yönelik daha fazla ders almaları ve Türkçe öğretmeni olma sorumluluğunun üzerlerinde baskı yaratmasının daha kaygılı olmalarına sebep olduğu şeklinde yorumlanabilir. Bağcı (2007) Türkçe öğretmeni adaylarının yazılı anlatıma ve yazılı anlatım derslerine yönelik tutumlarını değerlendirdiği çalışmasında da Türkçe öğretmeni adaylarının yazılı anlatım becerilerindeki yetersizliklerinden yakındıkları ve mesleki hayatlarında da bu alanda sıkıntı çekeceklerine inandıklarını belirtmiştir.

Araştırmada sınıf ve Türkçe öğretmeni adaylarının yazma kaygıları sınıf seviyelerine göre anlamlı bir farklılık göstermiştir. Sınıf öğretmeni adaylarından 4. sınıfta okuyanların yazma kaygıları 1, 2 ve 3. sınıfta okuyanlardan anlamlı derecede düşüktür. Türkçe öğretmeni adaylarından 2, 3 ve 4. sınıfta okuyanların yazma kaygıları ise birinci sınıftaki öğretmen adaylarının yazma kaygılarından anlamlı derecede düşüktür. Bu sonuç, İşeri ve Ünal (2012) ile Özdemir ve Erdem (2011) tarafindan yapılan öğrencilerin yazma yeterliliklerinin sinıflar arası birbirine benzer olduğu sonucuna vardıkları araştırmalarla tutarlılık göstermemektedir. Bunun yanında bu sonuç, ilköğretim öğrencilerinin yazma kaygılarını inceleyen Yaman (2010) tarafindan yapılan araştırmayla tutarlılık göstermektedir. Öğretmen yetiştirme programlarında, öğretmen adaylarının yazma yeterliklerinin ve bakış açılarının gelişimi çok önemlidir (Martinez ve Strong, 1994). Öğretmen adayları lisans eğitimlerinde yazma becerisiyle ilgili çeşitli dersler almaktadırlar. Bu derslerin öğretmen adaylarının yazma becerilerini geliştirmesi ve dolayısıyla yazma kaygılarını azaltması beklenmektedir. Öğretmen adaylarının üst sınıflarda yazma kaygılarının düşük olması bu beklentinin karşılandığını göstermektedir. $\mathrm{Bu}$ durumun aksine araştırmaya katılan öğretmen adaylarıyla yapılan görüşmelerde adayların büyük bir kısmı yazma becerisine yönelik alınan derslerin çok yetersiz olduğunu ve bu beceride kendilerini yetersiz gördüklerini ifade etmişlerdir. Mevcut alan yazın, öğrencilerin yazma becerilerinin nasıl geliştirileceği ve bu süreçte hangi yöntemtekniklerin kullanılabileceği konusunda öğretmen yetiştirme programlarının yetersiz olduğunu 
ortaya koymaktadır (Fry ve Griffin, 2010). Erdoğan'ın (2012) yaptığı araştırmaya katılan öğretmen adaylarının çoğunluğu üniversitede aldıkları eğitimin yazma stratejilerini kullanma konusunda hiç etkisi olmadığını veya olumsuz etkisi olduğunu ifade etmişlerdir. Öğretmen adayları genel olarak üniversitelerde aldıkları derslerde yazma becerisine yönelik çalışma, ödev veya araştırma yapmamaktadırlar. Bu durum öğretmen adaylarının yazma becerisinin gelişmemesine ve dolayısıyla kaygı durumlarının etkilenmesine sebep olmaktadır.

Araştırmada öğretmen adaylarının yazma kaygıları akademik not ortalamalarına göre anlamlı bir farklılık göstermemiştir. Öğretmen adayları lisans eğitimlerinde genel olarak sınavlarını çoktan seçmeli olarak olmaktadırlar (Erdoğan, 2012). Bu yüzden yazma becerisini gerektirecek sınav, ödev vb. araçlarla değerlendirilmemektedirler. Bu durum, öğretmen adaylarının yazma kaygılarının akademik ortalamalarını etkilemediği şeklinde yorumlanabilir.

Araştırmada öğretmen adayları dört temel dil becerisi içerisinde kendilerini en çok konuşma becerisinde başarılı hissettiklerini ifade etmişlerdir. Konuşma becerisini seçen katılımcılardan elde edilen sonuç konuşmada yazma ile kıyaslandığında kendilerini daha rahat ifade ettikleri olmuştur. Yazma; dinleme, okuma ve konuşma becerisinden sonra gelen, üst düzey becerileri kapsayan ve geliştirilmesi en zor beceridir' (Albertson ve Billingsley, 2000; Olinghouse ve Santangelo, 2010; Keklik, 2016). Bu durum kişilerin yazma becerisini çok fazla tercih etmemesine neden olmaktadır. Erdoğan (2012) tarafından yapılan araştırma da öğretmen adaylarının çoğunluğunun günlük yaşamlarında yazmaya çok fazla zaman ayırmadıklarını göstermektedir.

Araştırmada görüşme yapılan öğretmen adaylarının çoğunluğu yazmayı sevmediklerini ifade etmişlerdir. Bunun nedeni olarak yazma becerisine yönelik aldıkları lisans derslerinin yetersiz olduğunu belirtmişlerdir. Yazma becerisine yönelik derslerin adayları tatmin etmemesi bu becerilerinin gelişmesine ket vurabilir. Yeteri düzeyde alıştırma ve uygulama yapılmadan öğrenciden bu beceriyi sevmesi ve tek başına geliştirmesi beklenemez. Ayrıca yazma öğrenme sürecinde öğrencilerin kendi yeterliklerine olan inançları çok önemli bir rol oynar (Jones, 2008). Öz yeterliği (self-efficacy) yüksek olan kişiler, daha az kaygılıdırlar ve kaygılarını kontrol altında tutabilirler (Pajares, 1997). Yapılan araştırmalarda öğretim etkinliklerinde düzenli yazma çalışması yaptırılmasının öğrencilerin yaşadıkları yazma kaygısını önemli ölçüde azalttı̆̆ı vurgulanmaktadır' (Kardaş, 2015). Ceran (2013) ise yazma eğitimi dersinin teorik ve uygulamalı olarak iki yönlü hazırlandığını, yazma becerisini geliştirmeye yönelik derslerde teori ve uygulamanın birbirini tamamladığını ve herhangi birinin eksik kalması halinde bu becerinin gelişimini olumsuz etkileyeceğini düşünmektedir. Yazmayı seven adaylar ise kendilerini ifade etmede kolaylık ve psikolojik rahatlık sağladığı için yazmayı sevdiklerini belirtmişlerdir. Bilindiği üzere 'yazma, bireye duygu ve düşüncelerini somut bir biçimde ifade etme imkânı sunar' (Kan ve Tiryaki, 2015).

Araştırmaya katılan öğretmen adaylarının yarısından fazlası yazma kaygısı yaşadıklarını ifade etmişlerdir. Adaylar, yazılan yazıların ölçme ve değerlendirmeye alınması, yazıda zaman sınırlaması, yazının paylaşılması, yazma becerisinde yetersizlik duygusu ve öğretmen olma sorumluluğu gibi sebepleri kaygı sebebi olarak göstermişlerdir. Düşük not alma korkusu ile belirlenen süre içerisinde düşündüklerini tam olarak ifade edememe durumunun öğrencilerde kaygıya yol açtığı söylenebilir. Yazdığı yazı ile ilgili değerlendirilme süreci hakkında çeşitli ön yargılara sahip olan öğrencilerin duyuşsal olarak kaygılı olmaları muhtemeldir (Tomlinson, 1981). Ayrıca Heaton ve Pray (1982) yazma için yapılan zaman sınırlamasının ve öğretmenlerin olumsuz yorumlarının yazma kaygısı oluşturduğunu ifade etmişlerdir. Ayrıca öğretmen adaylarının bir kısmı öğretmen adayı olma sorumluluğunun yazma becerilerini olumsuz yönde etkilediğini belirtmişlerdir. Bir öğretmen adayı olarak dört temel dil becerisinin tamamında başarılı olmaları gerektiği beklentisi 
adayların geliştirilmesi en zor olan yazma becerisinden uzaklaşmalarına neden olduğu söylenebilir.

Sonuç olarak öğretmen adaylarının yazma kaygılarının düşük düzeyde olduğu, Sınıf ve Türkçe öğretmeni adaylarının yazma kaygıları arasında anlamlı bir fark olmadığı tespit edilmiştir. Ayrıca araştırmada elde edilen sonuçlar, cinsiyet ve akademik başarı değişkenlerinin yazma kaygısını etkilemediği, sınıf seviyesi değişkenin ise yazma kaygısını etkilediğini ortaya koymuştur. Yazma kaygısına yönelik öğretmen adaylarıyla yapılan görüşme sonuçları ise öğretmen adaylarının yarsından fazlasının yazma kaygısı yaşadıklarını göstermiştir.

$\mathrm{Bu}$ araştırma yalnızca Karadeniz Teknik Üniversitesi Eğitim Fakültesi sınıf ve Türkçe öğretmenliği programı 1, 2, 3 ve 4. sınıf öğrencileri ile yürütülmüştür. Benzer çalışmalar daha geniş örneklem grubu üzerinde, özellikle mülakata katılan öğrenci sayısının arttırılmasıyla gerçekleştirilebilir. Araştırmada elde edilen sonuçlar öğrencilerin yazma becerisine yönelik aldıkları derslerin yetersiz olduğunu ve bu beceri üzerinde yapılan alıştırma ve değerlendirmelerin yazmayı sevme ve yazma becerisinin gelişimini engellemeye zemin hazırladığını göstermektedir. Lisans düzeyinde yazma eğitimine yönelik dersleri daha verimli hale getirmek amaçlı değişiklikler yapılabilir veya söz konusu dersin/derslerin ders saat sayıları arttırılabilir. Ayrıca öğrencilerin zaman sınırlaması ve ölçme/değerlendirme konusunda kendilerini baskı altında hissettikleri uygulamalar yerine daha esnek yöntem ve teknikler kullanılabilir.

\section{KAYNAKÇA}

Albertson, L. R. ve Billingsley, F. F. (2000). Using strategy instruction and self-regulation to improve gifted students' creative writing. Journal of Advanced Academics, 12 (2), 90-101.

Aytan, N. ve Tunçel, H. (2015). Yabancı dil olarak Türkçe yazma kaygısı ölçeğinin geliştirilmesi çalışması. Mustafa Kemal Üniversitesi Sosyal Bilimler Enstitüsü Dergisi, 12(30), 50-62.

Bağcı, H. (2007). Türkçe öğretmeni adaylarının yazılı anlatıma ve yazılı anlatım derslerine yönelik tutumlarının değerlendirilmesi. TÜBAR-XXI, 29-61.

Bayat, N. (2014). The effect of the process writing approach on writing success and anxiety. Educational Sciences: Theory \& Practice, 14(3), 1133-1141.

Bruning, R. ve Horn, C. (2010). Developing motivation to write. Educational Psychologist, $35(1), 25-37$.

Calhoun, S. ve Haley, J. (2003). Improving student writing through different writing styles. Master Thesis. Chicago, Illinois: Saint Xavier University.

Ceran, D. (2013). Türkçe öğretmeni adaylarının yazma eğitimi dersine yönelik tutumlarının değerlendirilmesi. Turkish Studies, , 8(1), 1151-1169.

Cheng, Y. (2002). Factors associated with foreign language writing anxiety. Foreign Language Annals, 35, 647-656.

Creswell, J. W. (2014). Research design Çev.: Güney Haciömeroğlu, Ed.: Selçuk Beşir Demir. Ankara: Eğiten Kitap.

Creswell, J. W. (2008). Educational research. New Jersey: Pearson Education Inc. 
Daly, J. A. (1978). Writing apprehension and writing competency. The Journal of Educational Research, 72(1), 10-14.

Daly, J. ve Miller, M. D. (1975). The empirical development of an instrument to measure writing apprehension. Research in the Teaching of English, 9, 242-249.

DeDeyn, R. (2011). Student identity, writing anxiety, and writing performance: A correlational study. Master Thesis. Fort Collins, Colorado: Colorado State University.

Emig, J. (1977). Writing as a mode of learning. College Composition and Communication, 28, 122-128.

Erdoğan, T. (2012). Determining the level of the use of writing strategies by prospective classroom teachers. Internatıonal Journal of Academic Research, 4 (6), 49-56.

Fraenkel, J. R. ve Wallen, N. E. (2006). How todesignandevaluateresearch in education. New York: McGraw-HillCompanies.

Fry, S. W. ve Griffin, S. (2010). Fourth graders as models for teachers: Teaching and learning $6+1$ trait writing as a collaborative experience. Literacy Research and Instruction, 49(4), 283-298.

Gallavan, N.P., Bowles, F.A. ve Young, C.T. (2012). Learning to write and writing to learn: Insights from teacher candidates. Action in Teacher Education, 29(2), 61-69.

Göçer, A. (2010). Türkçe öğretiminde yazma eğitimi. Uluslararası Sosyal Araştırmalar Dergisi, 3 (12), 178-194.

Graham, S., Berninger, V. ve Fan, W. (2007). The structural relationship between writing attitude and writing achievement in first and third grade students. Contemporary Educational Psychology, 32, 516-536.

Güneyli, A. (2016). Analyzing writing anxiety level of Turkish cypriot students. Education and Science, 163-180.

Heaton, H. ve Pray, P. (1982).Writing anxiety: Reasons and reduction techniques. Wisconsin English Journal, 24(3), 2-7.

Jones, E. (2008). Predictingperformance in first-semestercollegebasicwriters: Revisitingthe role of self-beliefs. ContemporaryEducationalPsychology, 33, 209-238.

İşeri, K. ve Ünal, E. (2012). Türkçe öğretmen adaylarının yazma kaygı durumlarının çeşitli değişkenler açısından incelenmesi. Mersin Üniversitesi Ĕ̈itim Fakültesi Dergisi, 8(2), 67-76.

Kan, M. O. ve Tiryaki, E. N. (2015). Türkçe öğretmeni adaylarının metin oluşturmadaki sorunlar1. Mersin Üniversitesi Eğitim Fakültesi Dergisi, 11(2), 550-562.

Karakaya, İ. ve Ülper, H. (2011). Yazma kaygısı ölçeğinin geliştirilmesi ve yazma kaygısının çeşitli değişkenlere göre incelenmesi. Kuram ve Uygulamada Eğitim Bilimleri, 11(2), 691-707.

Karasar, N. (2015). Bilimsel araştırma yöntemi. Ankara: Nobel Yayınları.

Kardaş, M. N. (2015). İki dilli Türkçe öğretmeni adaylarının Türkçe yazılı anlatım becerileri ve yazma kaygıları üzerine bir araştırma. International Journal of Social Science, $37,239-252$. 
Kellogg, R. (2008). Training writing skills: a cognitivedevelopmentalperspective. Journal of WritıngResearch, 1(1), 1-26.

Keklik, S. (2016). Yazma eğitimiyle ilgili iki ders önerisi: düşünceye dayalı metin yazma ve kurmaca metin yazma dersi. International Journal of Turkish Education and Training, 1(1), 86-109.

Kurt, G. ve Atay, D. (2007). The effects of peer feedback on the writing anxiety of prospective Turkish teachers of EFL. Eğitimde Kuram ve Uygulama, 3(1), 12-23.

Lehrer, P., Goldman, N. ve Strommen, E. (1990). A principalcomponentsassessment of performanceanxietyamongmusicians. MedicalProblems of PerformingArtists, 5(1), $12-18$.

Martinez, C.T., Kock, N. ve Cass, J. (2011). Pain and pleasure in short essay writing: factors predicting university students' writing anxiety and writing self-efficacy. Journal of Adolescent \&Adult Literacy 54(5), 351-360.

Martinez, I. ve Strong, W. (1994). Assessing writing competence in teacher education. Action in Teacher Education, 16 (2), 28-36.

McLeod, S. (1987). Some thoughts about feelings: The affective domain and the writing process. College Composition and Communication, 38 (4), 426-435.

Olinghouse, N. G. ve Santangelo, T. (2010). Assessing the writing of struggling learners. Focus On Exceptional Children, 43 (4), 1-27.

Özdemir, N. H. ve Erdem, İ. (2011). Türkçe öğretmeni adaylarının yazma alışkanlıklarının bazı değişkenler açısından incelenmesi. Uşak Üniversitesi Sosyal Bilimler Dergisi, 4(2), 101-125.

Pajares, F. (1997). Currentdirections in self-efficacyresearch. In M. Maehr, \& P. R. Pintrich (Eds.), Advances in motivationandachievement (pp. 1-49). Greenwich, CT: JAI Press.

Petrosko, J.M., Kaiser, M.M. ve Dietrich, J.C. (1984). Relationships among writing ability, grade, level, writing apprehension and knowledge of composing as a process in secondary school students. presented at the AnnualMeeting of the American EducationalResearch Association (68th, New Orleans, LA).

Sevim, O. ve Özdemir Erem, N. H. (2013). Yaratıcı drama tekniğinin öğrencilerin yazma kaygıları üzerindeki etkileri. Adlyaman Üniversitesi Sosyal Bilimler Enstitüsü Dergisi, 6(11), 975-992.

Schweiker-Marra, K., Marra, T. (2010). Investigating the effects of prewriting activities on writing performance and anxiety of at-risk students. Reading Psychology, 99-114.

Street, C. (2003). Pre-service teachers' attitudes about writing and learning to teach writing: implications for teacher educators. Teacher Education Quarterly, 30 (3), 33-50.

Teichman, M. ve Poris, M. (1989). Initialeffects of wordprocessing on writingqualityandwritinganxiety of freshmanwriters. ComputersandtheHumanities, 23 (2), 93-103.

Tiryaki, E. N. (2012). Üniversite öğrencilerinin yazma kaygısının çeşitli değişkenler açısından belirlenmesi. Dil ve Edebiyat Eğitimi Dergisi, 1(1), 14-21.

Tok, M. ve Potur, Ö. (2015). Yazma eğitimi alanında yapılan akademik çalışmaların eğilimleri (2010 - 2014 Y1lları). Ana Dili Ĕ̆itimi Dergisi, 3(4), 1-25. 
Tomlinson, B. (1981). Reducingstudentwritinganxiety. Proceedings of theAnnual Conference of the Western College Reading Association, 14, 24-32.

Uçgun, D. (2011). The study in the writing anxiety levels of primary school 6, 7 and 8th year students in terms of several variables. Educational Research and Reviews. 6 (7) 542547.

Yaman, H. (2010). Türk öğrencilerinin yazma kaygısı: ölçek geliştirme ve çeşitli değisşkenler açısından yordama çalışması. International Online Journal of Educational Sciences, 2 (1), 267-289.

Yıldırım, A. ve Şimşek, H. (2013). Sosyal bilimlerde nitel araştırma yöntemleri. Ankara: Seçkin Yayıncılık.

Woodrow, L. (2011). College english writing affect: self- efficacy and anxiety. System 39, 510-522.

Wynne, C., Guo, Y. ve Wang, S. (2014). Writinganxietygroups: a creativeapproachforgraduatestudents. Journal of Creativity in MentalHealth, 9(3), 366-379.

Zorbaz, K. Z. (2010). İlköğretim okulu öğrencilerinin yazma kaygı ve tutukluğunun yazılı anlatım becerileriyle ilişkisi. Yayınlanmamış Doktora Tezi. Ankara: Gazi Üniversitesi Eğitim Bilimleri Enstitüsü. 